\title{
Surface Modification of Strenx 900 Steel Using Electrical Discharge Alloying Process with Cu-10Ni- $\mathrm{Cr}_{x}$ Powder Metallurgy Sintered Electrode
}

\author{
S. Sridhar * (1), Srinivas Viswanth Valetib, Vishwanath Kotic, S. Sathish ${ }^{d}$, R. Raghu Chand ${ }^{e}$, \\ N.S. Sivakumarf, Mahesh. Mg, Ram Subbiah ${ }^{h}$ (1), G. Veerappan ${ }^{i}$ \\ ${ }^{a}$ PSNA College of Engineering and Technology,Department of Mechanical Engineering, Dindigul. \\ ${ }^{b}$ Aditya Engineering College, Department of Mechanical Engineering, Andhrapradesh. \\ ${ }^{c}$ Ramaiah Institute of Technology, Department of Mechanical Engineering, Bangalore. \\ ${ }^{d}$ Ramakrishna Engineering College, Department of Mechanical Engineering, Coimbatore \\ ${ }^{e}$ Karavali Institute of Technology, Department of Mechanical Engineering, Mangalore. \\ ${ }^{f}$ TISHK International University, Department of Mechatronics Engineering, Iraq. \\ ${ }^{g}$ Guntur Engineering College, Department of Mechanical Engineering, Andhra Pradesh. \\ ${ }^{h}$ Gokaraju Rangaraju Institute of Engineering and Technology, Department of Mechanical Engineering, \\ Hyderabad. \\ ${ }^{i}$ Sri Krishna College of Engineering and Technology, Department of Mechatronics Engineering, \\ Coimbatore.
}

Received: July 29, 2021; Revised: December 04, 2021; Accepted: December 28, 2021

\begin{abstract}
The present investigation aims to coat the layer with Nickel $(\mathrm{Ni})$ and Copper $(\mathrm{Cu})$ over the surface of strenx 900 steel using semi sintered $\mathrm{Cu}-10 \mathrm{Ni}-\mathrm{Cr}_{\mathrm{x}}$ electrodes( $\mathrm{x}=2,4 \& 6 \mathrm{wt}$. \%). Three different proportions of semi sintered electrodes such as, $\mathrm{Cu}-10 \mathrm{Ni}-2$ weight percentage of Chromium $(\mathrm{Cr})$, $\mathrm{Cu}-10 \mathrm{Ni}-4$ wt. \% $\mathrm{Cr}$,and $\mathrm{Cu}-10 \mathrm{Ni}-6$ wt. \% $\mathrm{Cr}$ were prepared by powder metallurgy route. Electric discharge alloying was completed based on $\mathrm{L}_{9}$ orthogonal array and alloyed parameters were optimized using Taguchi method. The alloyed surfaces were characterized using scanning electron microscope and atomic force microscopy. The deposition of formation of intermetallic was studied using X- ray diffractometer. Higher Material Transfer Rate (MTR) was obtained at 9A, 350A and $6 \%$ chromium using $\mathrm{Cu}-10 \mathrm{Ni}-\mathrm{Cu}$ electrode. The chromium percentage was the foremost factor on Surface Roughness (SR) (73.71\%) and MTR(96.56\%). From Taguchi approach, the minimum SR was attained at percentage of chromium of $2 \%$, compaction pressure of 250 Megapascal (MPa) and peak current of 9A. The maximum MTR was achieved at 6 percentage of $\mathrm{Cr}$, compaction pressure of 350 $\mathrm{MPa}$ and peak current of $3 \mathrm{~A}$. Wear loss for $\mathrm{Cu}-10 \mathrm{Ni}-\mathrm{Cr}$ increases linearly with increase in sliding speed from $2 \mathrm{~m} / \mathrm{s}$ to $4 \mathrm{~m} / \mathrm{s}$ respectively.
\end{abstract}

Keyword: Electrical discharge alloying, Powder Metallurgy, Taguchi, Characterization, Atomic force microscopy.

\section{Introduction}

Electrical discharge machining is an unconventional machining process that involves eroding material from a work piece using a tool called electrode. The process occurs as a sequence of electrical discharges in the presence of dielectric fluid $^{1}$. In case of die sinking Electric Discharge Machining (EDM), the process should be carried out only with the dielectric fluids such as de ionized water; kerosene and EDM oil $^{2}$. EDM process is a suitable technique inmanufacturingof micro holes. It is also an economic, quick and cost effective for producing holes in hard and soft materials ${ }^{3}$. The undesirable layer was formed after machining known as recast layer which is inevitable but could be controlled by varying EDM process parameters. The harder recast layers, on the other hand are helpful in improving the wear resistance, as demonstrated by deliberate surface alloying during EDM. The use of

*e-mail: sri_2855@yahoo.co.in partially sintered Powder Metallurgy (PM) electrodes, EDM in a metal powder suspended dielectric are the most popular methods for performing alloying during EDM that were been widely adopted in the past ${ }^{4}$. The common methods of surface modification using EDM is carried out by two means such as, use of semi sintered electrode and mixing powder in dielectric ${ }^{5}$. The surface texture effects were based on the level of control factors ${ }^{6}$. By using Powder metallurgy tool electrodes, EDM tooling costs can be reduced while tool electrodes can be produced in more quantity

The surface of mould and tools has to be modified in order to increase their service life as well as withstand corrosion. Nevertheless, high machine price and complex processes makes to analyze novel surface modification processes ${ }^{8}$. During $\mathrm{EDM}$ of powder metallurgy of $\mathrm{Cu}-\mathrm{Zn}$, it was found that more contamination of dielectric medium was obtaineddue to the release of more copper powder from electrode. Poor surface 
topology was obtained due to the frequent occurrences of short circuits and arcs. It was pointed out that machining stability got affected more with increase in copper powder size 9 .Powder metallurgy of $\mathrm{Cu}-\mathrm{Cr}$ electrode yielded low Material Removal Rate (MRR), higher electrode wear ratio and high surface roughness, but electrolytic $\mathrm{Cu}$ electrode was better in achieving high MRR than powder metallurgy of $\mathrm{Cu}-$ $\mathrm{Cr}^{10}$. EDM of Titanium Aluminium Vanadium (Ti-6Al-4V) alloy with powder metallurgy of $\mathrm{Cu}$-Tantalum Carbide (TaC) electrode in urea solution dielectric yielded in the deposition of nitrides, carbides, oxides of titanium and tantalum on the substrate. The base surface hardness improved from 316 Vicker Hardness (HV) to $902 \mathrm{HV}^{11}$.During machining carbon steel by suspending tungsten and titanium powders in kerosene dielectric, formation of Titanium Carbide (TiC) and Tungsten Carbide (WC) were identified on substrate due to the reaction between decomposed carbon with titanium and tungsten powders ${ }^{12}$.

Very few researchers have carried out investigation on Electric Discharge Alloying (EDA) using $\mathrm{Cu}-\mathrm{Ni}-\mathrm{Cr}$ on strenx 900 steel. This investigation focuses on synthesis ofpowder metallurgy of $\mathrm{Cu}-10 \mathrm{Ni}-\mathrm{Cr}_{\mathrm{x}}$ electrodes produced at three different mixing ratios $(2,4$, and 6 wt. $\% \mathrm{Cr})$, compaction pressure $(250,300$, and $350 \mathrm{MPa})$ and peak current $(3 \mathrm{~A}$, $6 \mathrm{~A}$ and $9 \mathrm{~A})$.

\section{Materials and Methods}

\subsection{Preparation of PM semi sintered $\mathrm{Cu}-10 \mathrm{Ni}-\mathrm{Cr}_{x}$ electrode}

The elemental powders of copper, nickel and chromium were mixed in addition of polyvinyl alcohol using ball mill for 1 hour. The ratio of ball to powder is 10:1. The hydraulic press of $150 \mathrm{kN}$ was used to compact of copper, nickel, and chromium. Three different compaction pressureswere applied with 250, 300 and $350 \mathrm{MPa}$ for preparing the electrode. Constant hydraulic forces were applied for 10min using punch and then pallet was ejected using lab press. The compacted cylindrical billet dimension with $10 \mathrm{~mm}$ diameter and $20 \mathrm{~mm}$ length were obtained. The tubular furnace was brought to vacuum and the compacted specimens were heated in tubular furnace containing argon atmosphere and the heating rate for sintering is $10^{\circ} \mathrm{C}$ per min. The furnace temperature for sintering wasdone at $800^{\circ} \mathrm{C}$ and further, it was cooled down inside the furnace to achieve homogenous mixture of powder materials.

\subsection{Surface modification of strenx steel}

The sintered alloys were coated on thesurface of strenx steel plate. The substance compositions of the strenx steel were shown in Table 1. The positive polarity was applied to sintered electrode. The process parameters were shown in Table 2. By varying parameters, alloycharacteristics were analyzed. An $\mathrm{L}_{9}$ orthogonal array was used for conducting the experiment which is shown in Table 3. Surface roughness was measured using Mitutoyo SJ-400 tester over the alloyed surface. The surface topology of the modified layer was investigated using SEM with Energy Dispersive X-Ray Spectroscopy (EDS). Further, the alloyed surface was analyzed using atomic force microscopy.

\subsection{Wear measurement}

The pin substrates were alloyed by using three electrodes namely $\mathrm{Cu}-10 \mathrm{Ni}-2$ wt. $\%, \mathrm{Cu}-10 \mathrm{Ni}-4$ wt. $\%$, and $\mathrm{Cu}-10 \mathrm{Ni}-6$ wt $\%$. Wear test was conducted using tribometer of American Society for Testing and Materials (ASTM): G99-05. The pin was made to rotate against EN31 steel disc of $100 \mathrm{~mm}$ diameter. The weight loss of the pin was measured using $0.1 \mathrm{mg}$ precision electronic weighing balance.

Table 1. Substance composition of Strenx steel.

\begin{tabular}{ccccccccccc}
\hline $\mathrm{C}$ & $\mathrm{Si}$ & $\mathrm{Mn}$ & $\mathrm{P}$ & $\mathrm{S}$ & $\mathrm{Cr}$ & $\mathrm{Cu}$ & $\mathrm{Ni}$ & $\mathrm{Mo}$ & $\mathrm{B}$ & $\mathrm{Fe}$ \\
\hline 0.20 & 0.50 & 1.60 & 0.020 & 0.010 & 0.80 & 0.3 & 2 & 0.70 & 0.005 & remaining \\
\hline
\end{tabular}

Table 2. Control factors and their levels.

\begin{tabular}{ll}
\hline \multicolumn{1}{c}{ Machining Condition } & Description \\
\hline Work piece & Strenx 900 Steel \\
\hline Electrode material & Cu-Ni-Cr \\
\hline Dielectric & EDM oil 30 \\
\hline Polarity & $\begin{array}{l}\text { Strenx } 900 \text { rectangular plate: Negative } \\
\text { Copper tool: Positive }\end{array}$ \\
\hline Process parameter with their levels & \\
\hline Peak current & $3 \mathrm{~A}, 6 \mathrm{~A}, 9 \mathrm{~A}$ \\
\hline Compaction pressure & $250 \mathrm{Mpa}, 300 \mathrm{Mpa}, 350 \mathrm{Mpa}$ \\
\hline semi sintered electrode & $\mathrm{Cu}-10 \mathrm{Ni}-\mathrm{Cr}$ \\
\hline Constant Parameters & \\
\hline Gap Voltage $(\mathrm{V})$ & 50 \\
\hline Duty factor & $50 \%$ \\
\hline Spark Gap & $0.10 \mathrm{~mm}$ \\
\hline Flushing pressure & $0.8 \mathrm{~kg} / \mathrm{cm}^{2}$ \\
\hline
\end{tabular}




\section{Results and Discussion}

\subsection{Surface morphology of alloyed surface}

Figure 1a-b shows the surface morphology of alloyed surface. The lesser amount of nickel and chromium were deposited over the surface of strenx steel. The electrode material suspended in EDM 30 oil moved to the surface while applying peak current. Better surface roughness was obtained due to the positive polarity of the electrode and current density on anode is smaller than that on the cathode due to the superior radius of discharge mark on the anode ${ }^{13}$. From Figure 1b, it was evident that higher current discharge (9A) has produced craters along with deposition of nickel

Table 3. Experimental observations.

\begin{tabular}{|c|c|c|c|c|c|}
\hline S.No & Wt. $\%$ of $\mathrm{Cr}$ & $\begin{array}{c}\text { Compaction } \\
\text { pressure } \\
\mathrm{MPa} \\
\end{array}$ & $\begin{array}{c}\text { Peak current } \\
\text { A }\end{array}$ & $\begin{array}{l}\mathrm{SR} \\
\mu \mathrm{m}\end{array}$ & $\begin{array}{c}\text { MTR } \\
\mathrm{mg} / \mathrm{min}\end{array}$ \\
\hline 1 & 2 & 250 & 3 & 5.9177 & 91.60 \\
\hline 2 & 2 & 300 & 6 & 6.5000 & 107.00 \\
\hline 3 & 2 & 350 & 9 & 6.7611 & 110.40 \\
\hline 4 & 4 & 250 & 6 & 6.6777 & 190.00 \\
\hline 5 & 4 & 300 & 9 & 7.1000 & 208.50 \\
\hline 6 & 4 & 350 & 3 & 7.6111 & 230.80 \\
\hline 7 & 6 & 250 & 9 & 7.4377 & 281.23 \\
\hline 8 & 6 & 300 & 3 & 7.9494 & 311.20 \\
\hline 9 & 6 & 350 & 6 & 8.3711 & 329.70 \\
\hline
\end{tabular}
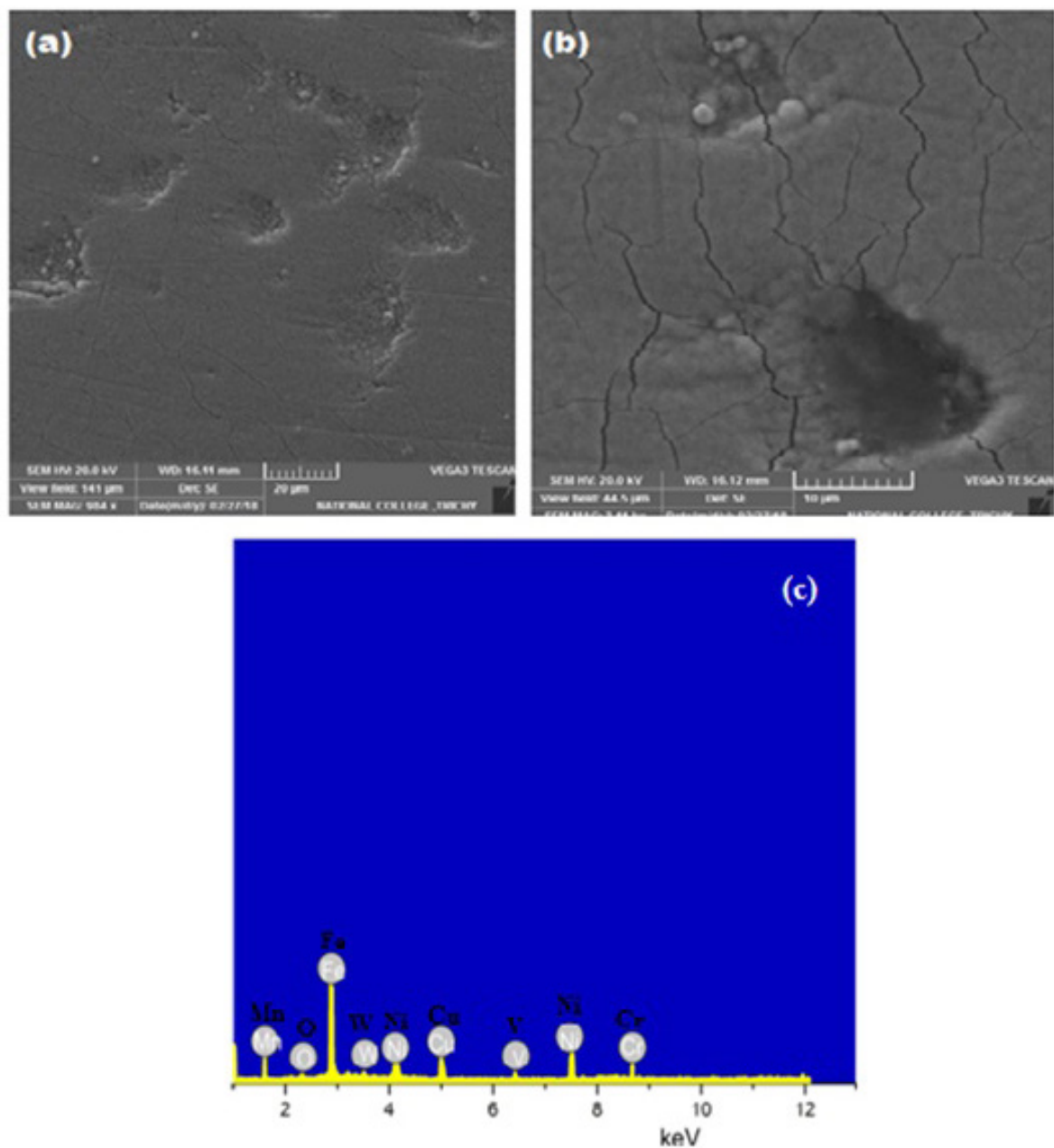

Figure 1. Scanning Electron Microscope (SEM) analysis of alloyed surface by $\mathrm{Cu}-10 \mathrm{Ni}-2 \mathrm{Cr}$ at (a) peak current of $6 \mathrm{~A}$, compaction pressure of $300 \mathrm{MPa}$ and $2 \mathrm{wt} . \% \mathrm{Cr}(\mathrm{b})$ peak current of $9 \mathrm{~A}$, compaction pressure of $250 \mathrm{Mpa}$ and $6 \mathrm{wt} \% \mathrm{Cr}(\mathrm{c})$ EDS result of modified layer using $\mathrm{Cu}-10 \mathrm{Ni}-2 \mathrm{Cr}$. 
and chromium. The formation of surface crack was obtained due to immediate quenching of fused metal in localization area. Figure 1c shows EDS result of the alloyed layer using $\mathrm{Cu}-10 \mathrm{Ni}-2 \mathrm{Cr}$. The nickel depositions were confirmed with corresponding peaks of nickel adjacent to ferrous peak.

Figure 2 shows the SEM and EDS results of alloyed layer. The evidence of materials deposited from tool electrode wasshown in EDS results. It was evident that surface of strenx steel was coated with nickel and chromium. EDS results has confirmed the deposition of chromium and nickel over surface. Higher percentage of $\mathrm{Cr}$ has improved the alloy content andusing semi sinteredCu-10Ni-6Cr electrode, $\mathrm{Cu}$ powder improves binding strength as well as conductivity for EDM machining. The addition of alloying element has both lower electrical conductivity as well as thermal conductivity in powder metallurgy electrode. The rates of erosion wasincreased and as a result, tool material got deposited on the substrate ${ }^{14}$.

\subsection{Surface morphology of atomic force microscopy}

Figure 3a shows the surface topology obtained at peak current of $3 \mathrm{~A}$ and compaction pressure of $250 \mathrm{MPa}$. Atomic force microscopy results revealed better surface finish which
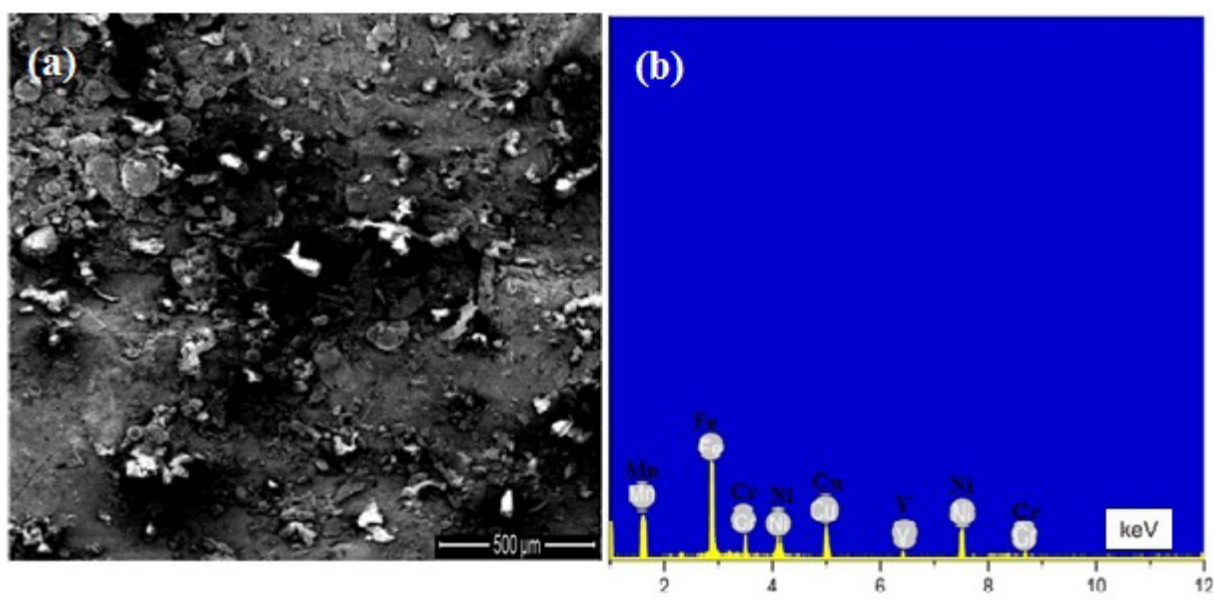

Figure 2. (a) SEM and (b) EDS result of the alloyed layer using $\mathrm{Cu}-10 \mathrm{Ni}-6 \mathrm{Cr}$ at peak current of $9 \mathrm{~A}$, compaction pressure of $250 \mathrm{Mpa}$ and 6 wt.\% Cr.
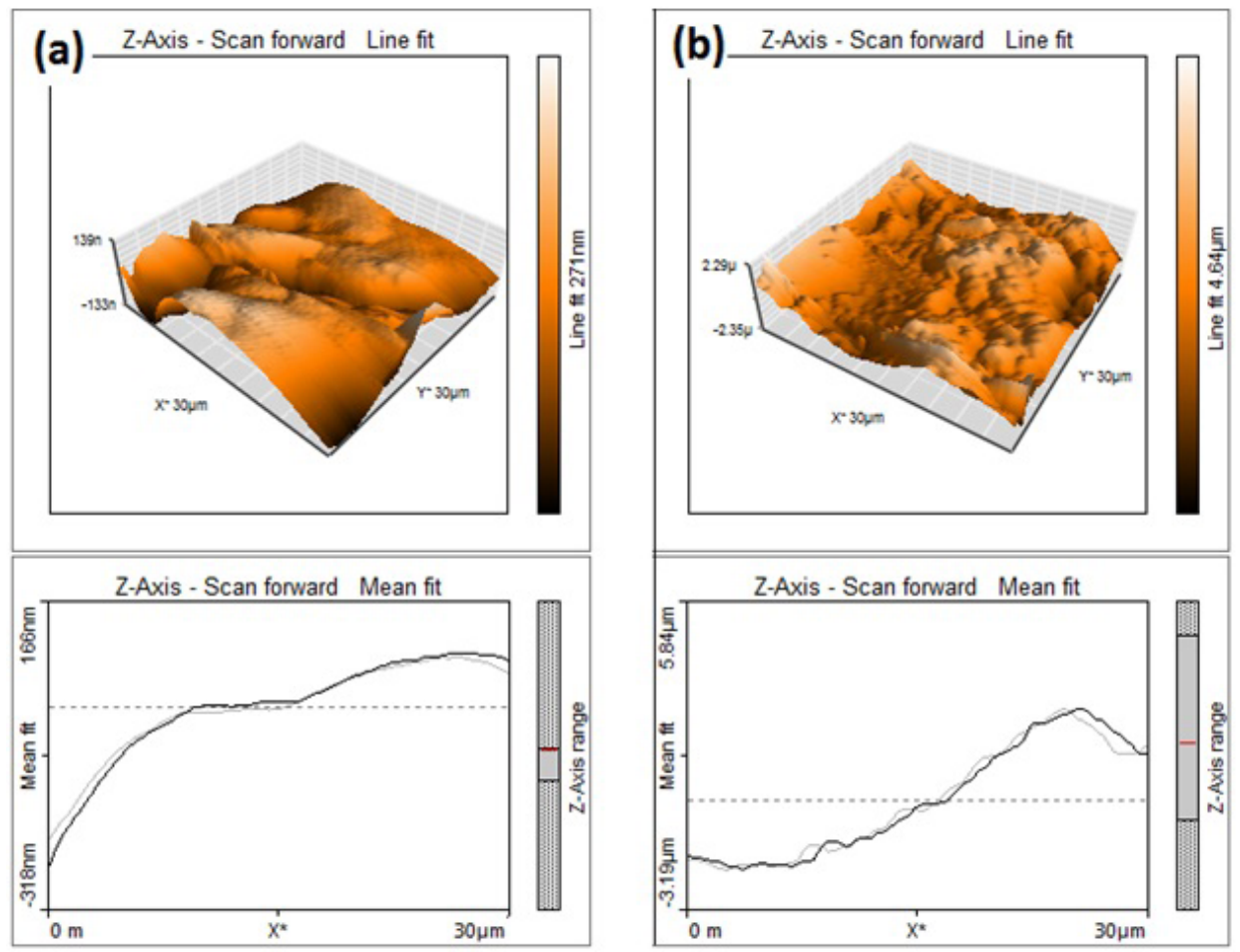

Figure 3. Atomic force microscopy results for the coated layer obtained (a) $3 \mathrm{~A}$, compaction pressure of $250 \mathrm{MPa}$ and $\mathrm{Cu}-10 \mathrm{Ni}-2 \% \mathrm{Cr}$ electrode (b) 6A, compaction pressure of $350 \mathrm{MPa}$ and $\mathrm{Cu}-10 \mathrm{Ni}-6 \% \mathrm{Cr}$ electrode. 
has no peaks and troughs. This finish was obtained due to the two reasons (a) the low compaction pressure which results in loose bonding of electrode particles and (b) nickel prevents secondary arcing which results in uniform discharge causes lower surface roughness ${ }^{15}$.

Figure $3 \mathrm{~b}$ shows the surface topology obtained at peak current of $6 \mathrm{~A}$ and compaction pressure of $350 \mathrm{MPa}$. At this set of parameters, high surface roughness was obtained due to deposition of more alloying elements of nickel and chromium. The reverse polarity of electrode causes to form more discharge energy which results in more alloying particles of electrode to fall on the work piece. These alloyed particles become bonded to the work piece during cooling by flush system $^{16}$. High chromium content released from electrode material forms bridging effect.

\subsection{ANOVA results}

From Table 4 and 5, Analysis of variance (ANOVA) results revealed that chromium content in electrode is the foremost in affecting surface roughness as well as material transfer rate, followed by compaction pressure. Therefore, chromium content and compaction pressure are the significant parameters towards SR and MTR. The higher chromium content improved MRR has reduced the electrode wear and enhanced the surface roughness ${ }^{17}$. The influential percentage contribution of chromium content, compaction pressure and peak current towards SR was found to be $73.71 \%$ and $25.93 \%$ and it's shown in Table 4 . Table 5 shows ANOVA results of material transfer rate. The influential percentage contribution of chromium content, compaction pressure and peak current towards SR were found to be $96.56 \%$ and $3.03 \%$ respectively. R- Squared values were closer to unit which makes model significant. Higher Material transfer rate was obtained at $9 \mathrm{~A}, 350 \mathrm{MPa}$ using $6 \%$ of chromium.

\subsection{Wear measurement}

Figure 4 shows the wear characteristics of prepared $\mathrm{Cu}-10 \mathrm{Ni}-\mathrm{Cr}_{\mathrm{x}}$ electrode. PM Cu-10 Ni without chromium content shows high wear compared to $\mathrm{Cu}-10 \mathrm{Ni}-\mathrm{Cr}_{\mathrm{x}}(\mathrm{x}=2$, 4 and 6 wt. $\% \mathrm{Cr}$ ). The wear loss increase steadily with an increase in sliding speed from $2 \mathrm{~m} / \mathrm{s}$ to $6 \mathrm{~m} / \mathrm{s}$. Wear loss for PM Cu-10 Ni-Cr $\mathrm{r}_{0}$ is high compared to the other alloy added with chromium. Wear loss for $\mathrm{Cu}-10 \mathrm{Ni}$-Crincreases linearly with an increase in sliding speed from $2 \mathrm{~m} / \mathrm{s}$ to $4 \mathrm{~m} / \mathrm{s}$. With

Table 4. Variance analysis for SR.

\begin{tabular}{|c|c|c|c|c|c|c|}
\hline Source /SR & DF & SS & MS & $\mathrm{F}$ & $\mathrm{P}$ & $\%$ \\
\hline$\%$ of $\mathrm{Cr}$ & 2 & 3.49656 & 1.74828 & 612.33 & 0.002 & 73.71 \\
\hline Compaction pressure & 2 & 1.22997 & 0.61499 & 215.40 & 0.005 & 25.93 \\
\hline Peak current & 2 & 0.01107 & 0.00554 & 1.94 & 0.340 & 00.23 \\
\hline Error & 2 & 0.00571 & 0.00286 & -- & -- & 00.13 \\
\hline Total & 8 & 4.74332 & -- & -- & -- & 100 \\
\hline$S=0.0534336$ & $\mathrm{R}-\mathrm{sq}=99.88 \%$ & & $\begin{array}{c}\text { R-sq(Adj)= } \\
99.52 \%\end{array}$ & & $\begin{array}{c}\text { R-sq(Pred })= \\
97.56 \%\end{array}$ & \\
\hline
\end{tabular}

Table 5. Variance analysis for MTR.

\begin{tabular}{lcccccc}
\hline \multicolumn{1}{c}{ Source $/$ MTR } & DF & SS & MS & F & P & $\%$ \\
\hline \% of $\mathrm{Cr}$ & 2 & 62696.7 & 31348.3 & 1123.06 & 0.001 & 96.56 \\
\hline Compaction pressure & 2 & 1968.0 & 984.0 & 35.25 & 0.028 & 03.03 \\
\hline Peak current & 2 & 208.2 & 104.1 & 3.73 & 0.211 & 00.32 \\
\hline Error & 2 & 55.8 & 27.9 & -- & -- & 00.09 \\
\hline Total & 8 & 64928.7 & -- & -- & -- & 100 \\
\hline S=5.28330 & \multicolumn{2}{c}{ R-sq= 99.91\% } & R-sq(Adj) $=99.66 \%$ & R-sq(Pred) $=98.26 \%$ \\
\hline
\end{tabular}

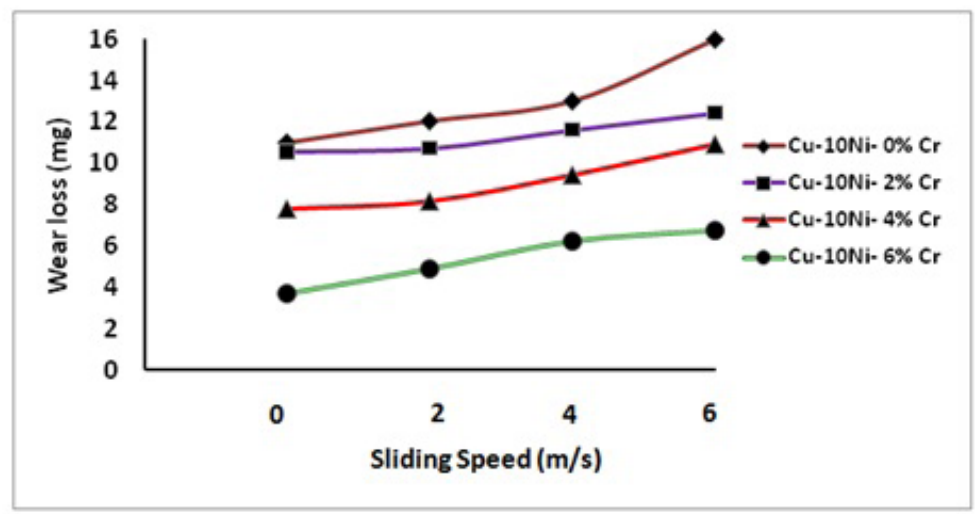

Figure 4. Wear behaviors of $\mathrm{Cu}-\mathrm{Ni}-\mathrm{Cr}$. 
subsequent increase in sliding speed from $4 \mathrm{~m} / \mathrm{s}$ to $6 \mathrm{~m} / \mathrm{s}$, there were no substantial loss in wear due to increase in chromium content. Sliding speed was the predominant factor to affect the wear rate in powder metallurgy based copper nickel alloy $^{18}$. The wear characteristics were found in magnesium alloy at different temperature conditions ${ }^{19}$.

\section{Surface Roughness}

The desirable SR value is found out from Taguchi approach. Based on the experimental objective, the SR value should be minimized. The surface roughness and its properties were enhanced through material deposition to the base alloys ${ }^{20,21}$. As per condition of the outcome, the lower the better is considered for SR. According to the criteria, Signal to Noise (SN) ratio and means are computed and it's shown in Table 6. SN ratio was used to reduce the error in design of experiment and uncertainty factors ${ }^{22}$. The quality characteristics and its effect on the responses were depends on $\mathrm{SN}$ ratio ${ }^{23}$. The significant factor of the process and its predicted model were controlled by $\mathrm{SN}$ ratio ${ }^{24}$.

Figure 5 shows that the main causes of SN ratio on SR. From the graph, the desirable $\mathrm{SR}$ value is attained at the level of $A_{1} B_{1} C_{3}$. Therefore, the minimum $S R$ is attained at percentage of chromium of $2 \%$, compaction pressure of $250 \mathrm{MPa}$ and peak current of $9 \mathrm{~A}$.

\section{Material Transfer Rate}

The aim of the investigation is to increase the material transfer rate. Hence, maximize the better criteria waschosen to achieve the MTR. Based on this condition, the mean and SN ratios are estimated and it's listed on the Table 7 . The optimal MTR is shown in Figure 6. The desirable MTR is obtained at $\mathrm{A}_{3} \mathrm{~B}_{3} \mathrm{C}_{1}$. Therefore, the maximum MTR is achieved at percentage of $\mathrm{Cr}$ of 6 , compaction pressure of $350 \mathrm{MPa}$ and peak current of $3 \mathrm{~A}$. The effect of compaction pressure on material transfer rate were investigated for

Table 6. Calculated SN ratio and means for SR

\begin{tabular}{|c|c|c|c|c|c|c|}
\hline \multicolumn{4}{|c|}{ SN ratio } & \multicolumn{3}{|c|}{ Means } \\
\hline Level & $\%$ of $\mathrm{Cr}$ & $\begin{array}{c}\text { Compaction } \\
\text { pressure }\end{array}$ & Peak current & $\%$ of $\mathrm{Cr}$ & $\begin{array}{c}\text { Compaction } \\
\text { pressure }\end{array}$ & Peak current \\
\hline 1 & -16.10 & -16.45 & -17.03 & 6.393 & 6.678 & 7.159 \\
\hline 2 & -17.05 & -17.10 & -17.07 & 7.130 & 7.183 & 7.183 \\
\hline 3 & -17.96 & -17.56 & -17.02 & 7.919 & 7.581 & 7.100 \\
\hline Delta & 1.86 & 1.11 & 0.05 & 1.526 & 0.903 & 0.083 \\
\hline Rank & 1 & 2 & 3 & 1 & 2 & 3 \\
\hline
\end{tabular}

Table 7. Calculated SN ratio and means for MTR.

\begin{tabular}{|c|c|c|c|c|c|c|}
\hline \multicolumn{4}{|c|}{$\mathrm{SN}$ ratio } & \multicolumn{3}{|c|}{ Means } \\
\hline Level & $\%$ of $\mathrm{Cr}$ & $\begin{array}{c}\text { Compaction } \\
\text { pressure }\end{array}$ & Peak current & $\%$ of $\mathrm{Cr}$ & $\begin{array}{c}\text { Compaction } \\
\text { pressure }\end{array}$ & Peak current \\
\hline 1 & 40.23 & 44.60 & 45.45 & 103.0 & 187.6 & 211.2 \\
\hline 2 & 46.41 & 45.61 & 45.51 & 209.8 & 208.9 & 208.1 \\
\hline 3 & 49.73 & 46.16 & 45.41 & 307.4 & 223.6 & 200.0 \\
\hline Delta & 9.51 & 1.56 & 0.10 & 204.4 & 36.0 & 11.2 \\
\hline Rank & 1 & 2 & 3 & 1 & 2 & 3 \\
\hline
\end{tabular}

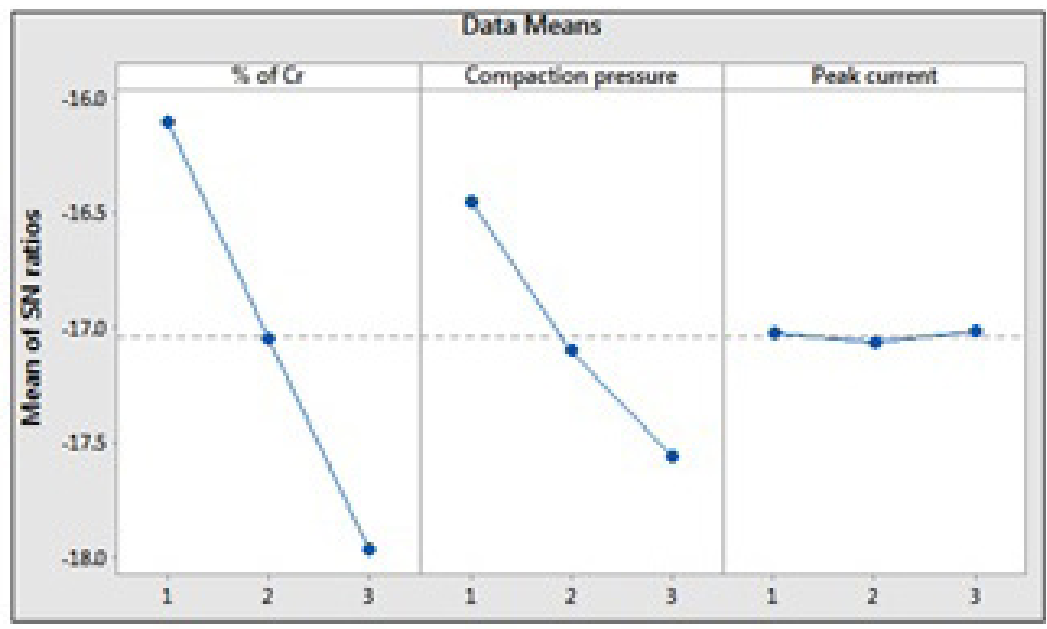

Figure 5. Desirable factor for SR. 


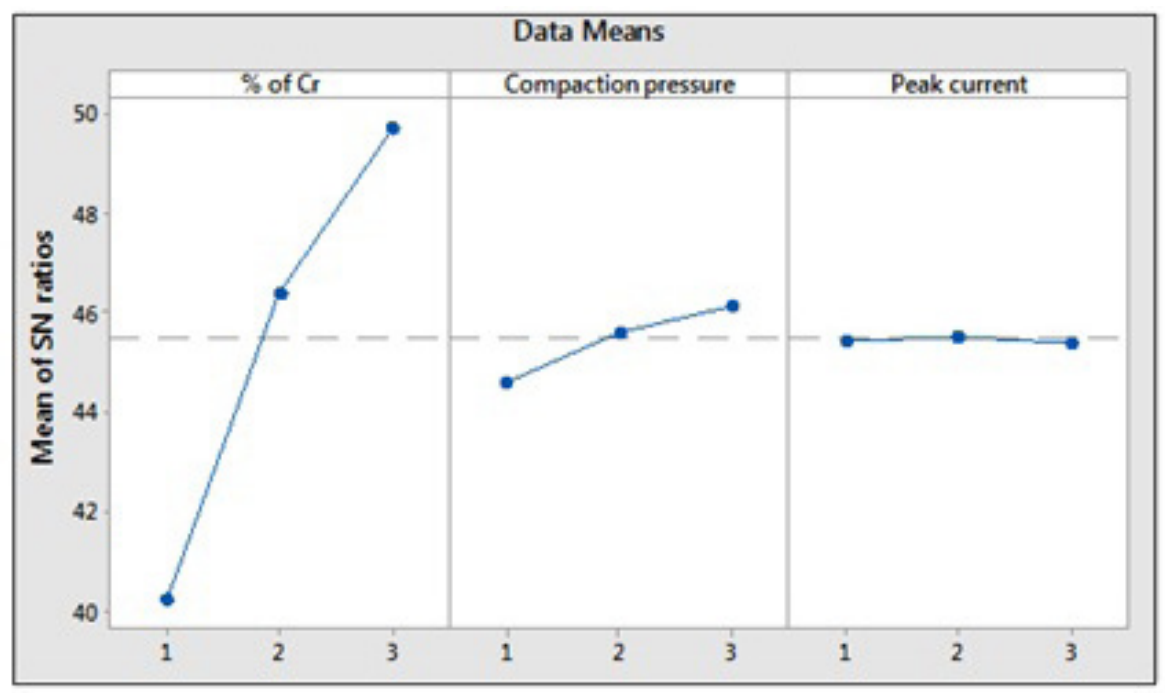

Figure 6. Desirable factor for MTR.

different alloys with forming temperature conditions ${ }^{25}$. The processing parameters and dynamic compaction system were played an essential role in material transfer rate ${ }^{26}$.

\section{Conclusion}

- $\quad$ Chromium, copper and nickel were deposited successfully over Strenx 900 steel using EDA process.

- Higher material transfer rate was obtained at 9A, 350A and $6 \%$ chromium using $\mathrm{Cu}-10 \mathrm{Ni}-\mathrm{Cu}_{6}$ electrode.

- $\quad$ EDS results revealed the presence of nickel, chromium and copper over Strenx steel 900.

- $\quad$ Strenx steel surface alloyed using $\mathrm{Cu}-10 \mathrm{Ni}-\mathrm{Cu}_{6}$ electrode showed less wear compared to the other synthesized electrode. Additon of chromium content in PM electrode has enhanced the wear resistance.

- Higher material transfer rate yielded in higher surface roughnesswere witnessed by peaks and troughs in atomic force microscopy analysis.

- Chromium content is the foremost factor in influencing material transfer rate and surface roughness followed by compaction pressure.

- From variance analysis, percentage of chromium was identified with dominant factor for SR (73.71\%) and MTR (96.56\%).

- $\quad$ From Taguchi approach,the minimum SR was attained at percentage of chromium of $2 \%$, compaction pressure of $250 \mathrm{Mpa}$ and peak current of $9 \mathrm{~A}$.

- The maximum MTR is achieved at percentage of Cr of 6, compaction pressure of $350 \mathrm{MPa}$ and peak current of $3 \mathrm{~A}$.

\section{References}

1. Puertas I, Luis CJ. A study of optimization of machining parameters for electrical discharge machining of boron carbide. Mater Manuf Process. 2004;19(6):1041-70.

2. Liu Y, Chang H, Zhang W, Ma F, Sha Z, Zhang S. A simulation study of debris removal process in ultrasonic vibration assisted electrical discharge machining (EDM) of deep holes. Micromachines. 2018;9(8):378. https://doi.org/10.3390/mi9080378.

3. Marichamy S, Saravanan M, Ravichandran M, Veerappan G. Parametric optimization of electrical discharge machining process on alpha beta brass using grey relational analysis. J Mater Res. 2016;31(16):2531-7.

4. Arun I, Vaishnavi P, Duraiselvam M, Senthilkumar V, Anandakrishnan V. Development of carbide intermetallic layer by electric discharge alloying on AISI-D2 tool steel and its wear resistance. Int J Mater Res. 2014;105(6):544-51.

5. Muttamara A, Kanchanomai C. Effect of carbon in the dielectric fluid and workpieces on the characteristics of recast layers machined by electrical discharge machining. Metall Mater Trans, A Phys Metall Mater Sci. 2016;47(6):3248-55.

6. Guu YH, Hou MTK. Effect of machining parameters on surface textures in EDM of Fe-Mn-Al alloy. Mater Sci Eng: A. 2007;466(1-2):61-7.

7. Naveen B, Maheshwari S, Sharma C. Performance evaluation of powder metallurgy electrode in electrical discharge machining of AISI D2 steel using Taguchi method. Int J Aerospace Mech Eng. 2008;2(3):167-71.

8. Chen YF, Chow HM, Lin YC, Lin CT. Surfacemodification using semi-sintered electrodes on electrical discharge machining. Int J Adv Manuf Technol. 2008;36(5-6):490-500.

9. Samuel MP, Philip PK. Powder metallurgy tool electrodes for electrical discharge machining. Int J Mach Tools Manuf. 1997;37(11):1625-33.

10. Gulcan O, Uslan I, Usta Y, Çogun C. Effect of use of Cu-Cr $\mathrm{P} / \mathrm{M}$ electrodes on machining performance of electric discharge machining. J Fac Eng Archit Gaz. 2015;30(3):381-94.

11. Ndaliman MB, Khan AA, Ali MY. Formation of nitrides and carbides on titaniumalloy surface through EDM. Adv Mat Res. 2012;576:7-10

12. Furutani K, Saneto A, Takezawa H, Mohri N, Miyake H. Accretion of titanium carbide by electrical discharge machining with powder suspended in working fluid. Precision Eng. 2001;25(2):138-44.

13. Rao PS, Purnima NS, Prasad DS. Surface alloying of D2 steel using EDM with WC/Co P/M electrodes made of Nano and Micron sized particles. Mater Res Express. 2018;6(3):036511.

14. Arun I, Yuvaraj C, Madhu A, Ramesh T. A comparison on microstructure and mechanical properties of electric discharge 
metal matrix nickel and silica composite coating on duplex stainless steel. J Compos Mater. 2021;55(4):002199832095388. https://doi.org/10.1177/0021998320953882.

15. Bai CY, Koo CH. Effects of kerosene or distilled water as dielectric on electrical discharge alloying of superalloy Haynes 230 with Al-Mo composite electrode. Surf Coat Technol. 2006;200(12-13):4127-315.

16. Gill AS, Kumar S. Surface characteristics investigations of tool steel machined by powder metallurgy tool in EDA. Mater Res Express. 2019;6:1-14.

17. Gulcan O, Uslan I, Usta Y, Çogun C. Effect of use of $\mathrm{Cu}-\mathrm{Cr}$ $\mathrm{P} / \mathrm{M}$ electrodes on machining performance of electric discharge machining. J Fac Eng Archit Gaz. 2015;30(3):381-94.

18. Cheng J, Gan X, Li Z, Lei Q, Zhou K. Wear map for sliding wear behavior of $\mathrm{Cu}-15 \mathrm{Ni}-8 \mathrm{Sn}$ alloy against bearing steel under oil-lubricated condition. J Cent South Univ. 2020;27(2):311-24. http://dx.doi.org/10.1007/s11771-020-4297-y.

19. An J, Zhang YX, Lv XX. Tribological characteristics of Mg$3 \mathrm{Al}-0.4 \mathrm{Si}-0.1 \mathrm{Zn}$ alloy at elevated temperatures of $50-200{ }^{\circ} \mathrm{C}$. Tribol Lett. 2018;66:14

20. Góral A, Lityńska-Dobrzyńska L, Kot M. Effect of surface roughness and structure features on tribological properties of electrodeposited nanocrystalline $\mathrm{Ni}$ and $\mathrm{Ni} / \mathrm{A} 12 \mathrm{O} 3$ coatings. J Mater Eng Perform. 2017;26(5):2118-28.

21. Góral A. Nanoscale structural defects in electrodeposited Ni/ A12O3 composite coatings. Surf Coat Tech. 2017;319:23-32.

22. Moayyedian M, Derakhshandeh JF, Said S. Experimental investigations of significant parameters of strain measurement employing Taguchi method. SN Appl Sci. 2019;1(1):92.

23. Md-Ralib AA, Mortada O, Orlianges JC, Crunteanu A, Chatras M, Nordin AN. J Mater Sci Mater Electron. 2017;28(1):9132-8. http://dx.doi.org/10.1007/s10854-017-6647-6.

24. Baligidad SM, Chandrasekhar U, Elangovan K, Shankar S. Taguchi's Approach: design optimization of process parameters in selective inhibition sintering. Mater Today. 2018;5(2 Pt 1):4778-86. http://dx.doi.org/10.1016/j.matpr.2017.12.051.

25. Radchenko AK. Mechanical properties of green compacts. II. Effect of powder relative bulk density on the strength of compacts with different forming temperature conditions. Powder Metall Met Ceramics. 2004;43(11-12):552-63.

26. Sethi G, Myers NS, German RM. An overview of dynamic compaction in powder metallurgy. Int Mater Rev. 2008;53(4):21934. http://dx.doi.org/10.1179/174328008X309690. 